\title{
TP73 wt Allele
}

National Cancer Institute

\section{Source}

National Cancer Institute. TP73 wt Allele. NCI Thesaurus. Code C49424.

Human TP73 wild-type allele is located in the vicinity of $1 \mathrm{p} 36.33$ and is approximately $1 \mathrm{~kb}$ in length. This allele, which encodes tumor protein p73, plays a role in the cell cycle and is frequently deleted in neuroblastoma and other cancers. 